\title{
SOBRE OS MONSTROS DO SENHOR COGITO - UMA REFLEXÃO SOBRE A HISTÓRIA E SERVIÇOS SECRETOS NA VIDA E NA OBRA DE ZBIGNIEW HERBERT
}

\author{
On The Monsters Of Mister Cogito - A Reflection On History And Secret \\ Services In The Life And Works Of Zbigniew Herbert
}

Piotr KILANOWSKI

Universidade Federal do Paraná

emaildopiotr@gmail.com

https://orcid.org/0000-0003-0803-4291

\begin{abstract}
RESUMO: O texto pretende apresentar uma reflexão sobre a vida e a obra de Zbigniew Herbert e evidenciar a sua interpenetração. A leitura proposta demonstra como a obra do poeta consegue ser lida ao mesmo tempo de forma universal e permeada de alusões autobiográficas. Entre variados monstros do Senhor Cogito me concentro em dois: a história e os serviços secretos. Desde a perda da sua cidade natal, a experiência dos dois totalitarismos, até a característica da obra herbertiana que Stanisław Barańczak definiu como deserdamento, a história aparece como um monstro, fascinante e devastador na vida do poeta e da sua geração, um monstro cuja marca em sua obra procuro mostrar ao longo do texto. Os serviços secretos que a partir do fim dos anos sessenta devassam a vida do poeta tentando manipulá-lo, potencializar sua doença psíquica e dificultar sua vida prática podem ser vistos como agentes da história cuja sombra é lançada também em seus versos. Procurando relatar a presença da sua influência na vida de Herbert, apresento leituras de seus poemas que ao mesmo tempo em que evidenciam essa influência, conseguem ser lidos de maneira universal e surpreendentemente atual nos tempos de hoje. PALAVRAS-CHAVE: Zbigniew Herbert; Poesia polonesa; História da Polônia; Biografia.
\end{abstract}

ABSTRACT: The text intends to present a reflection on the life and work
of Zbigniew Herbert and highlight its interpenetration. The proposed
reading demonstrates how the poet's work can be read at the same time in
a universal way and permeated with autobiographical allusions. Among
Mr. Cogito's various monsters, I focus on two: history and secret services.
From the loss of his hometown, the experience of two totalitarianisms,
to the characteristic of the Herbertian work that Stanisław Barańczak
defined as disinheritance, history appears as a fascinating and
devastating monster in the life of the poet and his generation, a monster
whose mark in his works I try to show throughout the text. The secret 
services that, from the end of the sixties, ravage the life of the poet trying to manipulate him, potentiate his psychic illness and hinder his practical life can be seen as agents of history whose shadow is also cast on his verses. Trying to report the presence of his influence in Herbert's life, I present readings of his poems that, while showing this influence, can be read in a universal and surprisingly current way in today's times. KEYWORDS: Zbigniew Herbert; Polish poetry; Polish history; Biography.

STRESZCZENIE: Niniejszy tekst ma na celu prezentację refleksji na temat życia i dzieła Zbigniewa Herberta i ukazanie wzajemnego przenikania się obu tych sfer. Proponowana interpretacja pokazuje, $\mathrm{w}$ jaki sposób twórczość poety może być odczytywana jednocześnie jako dzieło uniwersalne i autobiograficzne, dogłębnie przesiąknięte aluzjami nawiązującymi do doświadczeń poety. Z różnych potworów Pana Cogito zwracam szczególną uwagę na dwa: historię i służby bezpieczeństwa. Począwszy od utraty rodzinnego miasta, poprzez doświadczenie obu totalitaryzmów dzieło Herberta jawi się, wedle interpretacji Stanisława Barańczaka, jako rozdarte pomiędzy dziedzictwem a wydziedziczeniem. Historiaukazanaw nimjest jako potwór, któryzarazemfascynujeiniszczy życie poety i jego pokolenia, potwór, którego ślad w jego twórczości staram się pokazać w niniejszym tekście. Tajne służby, które od końca lat sześćdziesiątych inwigilują poetę, próbując nim manipulować, potęgować jego chorobę psychiczną i utrudniać jego życie, praktyczne mogą być postrzegane jako agenci historii, a ich cień jest dostrzegalny również w jego wierszach. Próbuję ukazać obecność tej inwigilacji i jej wpływ na życie Herberta i przedstawiam interpretacje wierszy, które go ukazują a jednocześnie mogą być odczytane w sposób uniwersalny i zaskakująco aktualny w dzisiejszej rzeczywistości brazylijskiej. SŁOWA KLUCZOWE: Zbigniew Herbert; Poezja polska; Historia Polski; Biografia.

O presente ensaio propõe uma reflexão a respeito da vida e da obra do grande poeta polonês Zbigniew Herbert (1924-1998) e evidencia a interpenetração de múltiplos elementos nessa obra escrita num palimpsesto composto de muitas camadas de sentido. Vários monstros perpassam essa obra. No meio deles tendo a me concentrar em dois: a história e os serviços secretos. A história para Herbert e para muitos dos seus coetâneos e compatriotas aparece com a dupla face: por um lado uma narrativa gloriosa e heroica, por outro a vivência caótica de mortes e violências sofridas. A perda da sua cidade natal e a vivência sob a opressão dos totalitarismos comunista e fascista levam à característica da 
obra herbertiana que Stanisław Barańczak definiu como deserdamento ${ }^{1}$

A história aparece na vida do poeta e da sua geração como um monstro, fascinante e devastador, um monstro cuja marca em sua obra procuro mostrar ao longo desse texto. Os serviços secretos que a partir do fim dos anos sessenta devassam a vida do poeta tentando manipulá-lo, potencializar sua doença psíquica e dificultar sua vida prática podem ser vistos como agentes da história cuja sombra é lançada também em seus versos. Procurando relatar a presença da sua influência na vida de Herbert, apresento leituras de seus poemas que ao mesmo tempo em que evidenciam essa influência, conseguem ser lidos de maneira universal e surpreendentemente atual nos tempos de hoje.

Uma das mais notáveis qualidades da poesia de Herbert é a habilidade de escrever poemas que ao mesmo tempo são absolutamente universais e profundamente pessoais, os poemas cuja leitura pode acontecer em várias camadas que encerram em si as experiências pessoais, geracionais, nacionais e universais. Mais do que isso, a habilidade poética de Herbert faz com que esses poemas sejam expressões que muitos dos seus leitores sintam como aquilo que eles mesmos gostariam de dizer a respeito de suas próprias vivências. Foi assim que Herbert tornou-se um poeta nacional na Polônia nos tempos da opressora decadência do sistema comunista, foi assim que foi tratado como a voz poética que encantou os intelectuais da Alemanha e dos Estados Unidos nos anos sessenta e setenta do século XX.

Sob a roupagem clássica e sóbria, seus poemas refletem também a sua conturbada vida. Herbert foi exilado da sua cidade natal com a qual sentiu-se fortemente ligado até o fim dos seus dias. A cidade polonesa de Lwów, invadida pelos soviéticos em setembro de 1939 por decreto de Stalin, depois da Segunda Guerra foi incorporada à União Soviética e depois da sua queda permaneceu na Ucrânia e hoje é chamada de Lviv. O poeta nunca se decidiu a visitá-la depois de ser expatriado, por considerar uma tal confrontação dolorosa demais, mas observava suas feições em inúmeras cidades que visitou em sua vida de "apóstolo numa viagem a trabalho" (HERBERT, Um postal a Adam Zagajewski, In: KILANOWSKI, 2018, p. 815) ${ }^{2}$. A deserdação da cidade natal talvez seja a o início daquilo

\footnotetext{
${ }^{1}$ Stanisław Barańczak (1946-2014), poeta, tradutor e estudioso de literatura, faz do conflito entre a deserdação e a herança um dos eixos da sua leitura da obra herbertiana apresentada em fascinante livro Uciekinier z Utopii (BARAŃCZAK, 1984).

${ }^{2}$ Todas as traduções nesse trabalho são de minha autoria, a não ser quando indicado diferente. Traduzi a obra poética completa de Herbert como anexo da tese de doutorado a seu respeito (KILANOWSKI, 2018) e doravante irei citá-los a utilizando como fonte colocando, quando for preciso, o nome do poema além do endereço bibliográfico. Cabe dizer que algumas das discussões a respeito da história na primeira parte deste ensaio são retomadas e revisões das análises feitas ao longo dessa tese.
} 
que foi visto como um dos principais marcos da sua obra notado por Stanisław Barańczak. O estudioso em seu trabalho contrapõe o mundo da herança (mítica, cultural, humanista) e o mundo do deserdamento. Para entendermos um pouco melhor essa oposição entre a herança e o deserdamento, vejamos o que diz sobre eles Barańczak:

[...A] herança abarca territórios de valores precisamente definidos e delimitados; o deserdamento é um estado no qual esses valores são sujeitos a um tipo de dissolução, turvação, apagamento, um estado no qual tanto indivíduos quanto nações ou civilizações são ameaçados de serem 'asfixiados por informidade' ("O monstro do Senhor Cogito") (BARAŃCZAK, 1984, p. 38).

Assim Herbert fala da sua cidade:

Nasci na cidade situada sobre uma grande divisão de águas, no meio do caminho entre o Mar Báltico e o Mar Negro. Um lugar singular nesta Terra. Por lá passei os felizes anos da infância e o início da juventude. Deixei-a há mais de um quarto de século, para nunca mais voltar. Era mais êxodo que uma partida espiritual e, embora eu esteja conciliado com a inevitabilidade histórica, lembro-me bem da minha cidade natal e, sobretudo, da lição que me ministrou. Hei de lembrá-la por toda a vida. Ela formou a minha primeira visão de Europa.

Esta cidade da minha infância era situada numa grande encruzilhada dos caminhos que levavam do ocidente ao oriente e do sul ao norte. As muralhas defensoras medievais, a catedral gótica, os belos prédios de apartamentos renascentistas na praça do mercado, as igrejas barrocas formavam um todo surpreendentemente harmônico que impressionava todo ádvena. E eram muitos os ádvenas que frequentemente ficavam aqui para sempre. Assim durante longos séculos formou-se um mosaico de muitas culturas e nações.

Quando vários anos depois viajei pela Europa Ocidental, procurava instintivamente pelas cidades e países nos quais era possível apreciar a presença de muitas camadas culturais, aparentemente contrárias entre si. Me atraía a Sicília com os vestígios de Gregos, Árabes e Normandos, pois eu pressentia que aquilo que é importante não apenas na arte, mas também na vida, surge num embate pacífico entre variados ideais e pensamentos. [...]

As lembranças obviamente colorem a realidade e talvez a minha cidade natal era na realidade menos bela do que me parece. Não surgiu por lá nenhum novo estilo artístico, não era um lugar de atuação nem de Rembrandt, nem de Leonardo, mas aos estudiosos impressionava uma tonalidade particular, um sotaque não encontrado em nenhum outro lugar. De acordo com os historiadores da arte, a particularidade consistia numa feliz junção, numa simbiose de elementos nativos, ocidentais, bizantinos e orientais. Durante séculos trabalhavam na minha cidade 
artistas italianos, holandeses, alemães, armênios, poloneses e rutenos. Decerto não era apenas uma coincidência feliz. Era algo que exigia a criação das condições sócio-políticas e também espirituais, bem como a grande tolerância, a hospitalidade para com os estranhos, a falta de preconceitos e de superstições religiosos e raciais. Assim minha primeira Europa - e estou a ela apegado até hoje - era um grande bazar de línguas, costumes e culturas (HERBERT, 2008b, p. 127-128).

Em outro lugar diz o poeta: "minha Lwów [...] era uma cidade polonesa, ucraniana e judia, mas também italiana, com aquela sua irreproduzível doçura, eterno sorriso, humor e heroísmo, aquele de guerra e aquele cotidiano" (HERBERT, 2008b, p. 179). A presença continua da cidade natal podemos observar quando o poeta viaja pela Itália e escolhe como predileta a Ferrara, pois na sua visão era "é a cidade mais parecida com Lwów", como escreveu Herbert para seu amigo italiano Francesco Cataluccio (1999, p. 35) ou no poema Rovigo. (Ferrara/ que eu amava por me lembrar/ da roubada cidade dos meus pais (HERBERT In: KILANOWSKI, 2018, p. 834). A cidade que lhe foi tirada pela história é apenas um exemplo da atuação da história e de sua forte marca na obra do poeta. Um outro exemplo poderia ser a casa do poema A casa (HERBERT In: KILANOWSKI, 2018, p. 501) que destruída pela guerra permanece apenas no íntimo como um conjunto de valores. A cidade perdida, além de ser um dos topoi da sua poesia, aparece em particular nos poemas como: Minha cidade (HERBERT In: KILANOWSKI, p. 572), Castelo Alto (HERBERT In: KILANOWSKI, p. 860), O Senhor Cogito: Uma aula de caligrafia (HERBERT In: KILANOWSKI, p. 864), Sobre Troia (HERBERT In: KILANOWSKI, p. 512), Nunca de você (HERBERT In: KILANOWSKI, p. 556) ou Na cidade (HERBERT In: KILANOWSKI, p. 858).

Nos seus poemas a história sempre aparece na sua dimensão terrível, desumana, ou talvez demasiadamente humana. A musa da história, Clio, é assim apresentada no livro Król mrówek (O rei das formigas) que reúne os apócrifos mitológicos de Herbert: "uma garota robusta, tosca, forte que nem um cavalo e inexprimivelmente ordinária - a deusa dos usurpadores, que repete seus bordões teimosos" (HERBERT, 2008a, p. 43). Małgorzata Mikołajczak (2005, p. 105), ao estudar a História em Herbert compara a aparência da musa a "os netos do Aurora/ rapazes com caras de batata/ as moças muito feias de mãos avermelhadas" do poema $O$ poder do gosto (HERBERT In: KILANOWSKI, 2018, p. 766). É semelhante a visão da história no poema inacabado, que iria servir como o título do seu último livro, Epílogo da tempestade. Nele fala Próspero, que de acordo com a tradição herbertiana de escrever apócrifos, nas quais histórias conhecidas ganham finais diferentes, permanece na ilha junto com Calibã: 
estou seguro de que Alonso altercará com Antônio na primeira oportunidade ou sem oportunidade pela maçã bichada do reino de Nápoles e aquele mais rápido degolará o irmão e depois outros começarão a assassinar uns aos outros às cegas trair incitar rebeliões tecer intrigas ou seja fazer história para que Clio possa escrever queimar de novo escrever e falsificar o livro para os descendentes a história das lutas das formigas negras com as vermelhas (HERBERT, In: KILANOWSKI, 2018, p. 874)

O tom parecido pode ser encontrado num outro poema de Herbert, fascinado pelo toco de sequoia no parque Yellowstone, no qual alguém colocou nos anéis da árvore marcas da história, comparando o mundo natural com o mundo histórico, fazendo parecer que os dois fossem harmônicos. O poeta que escreve no poema "Elegia para a partida da pena da tinta e da lâmpada":

Nunca acreditei no espírito da história um monstro fantasioso de olhar assassino uma besta dialética na trela dos algozes $[\ldots]$ levei anos para conhecer as grosseiras engrenagens da história a procissão monótona e o combate desigual sicários à frente das multidões aparvalhadas contra um punhado de justos e sensatos (HERBERT, In: KILANOWSKI, 2018, p. 803)

não tem dúvida que esses mundos não sejam harmônicos, fora da narrativa humana, fora da mitificação que fazemos em busca de sentido:

o Tácito desta árvore era um geômetra não conhecia adjetivos não conhecia a sintaxe que expressa o pavor não conhecia palavra alguma então calculava adicionava anos e séculos como se quisesse dizer que não há nada além de nascimento e morte nada apenas nascimento e morte e dentro a sangrenta polpa da sequoia (HERBERT, In: KILANOWSKI, 2018, p. 686)

Uma marca simbólica da influência da história na vida e na obra do poeta é evidenciada no poema $O$ Senhor Cogito. Uma aula de caligrafia. Aparece nele o sobrenome, coincidentemente significativo, da professora que lhe ensinou a escrever: 
Bomba. Nos seus anos da juventude Herbert aprendeu a ler história de um modo diferente, libertando-se da narrativa do mito criado por vencedores e lendo "Lívio contra Lívio" (HERBERT, As metamorfoses de Livio In: KILANOWSKI, p. 775). E na maturidade fala assim da sua visão dela, a partir da posição de seu prisioneiro:

Todos, no entanto, todos sem exceção estamos enredados na história, ou para usar essa imagem macabra, somos prisioneiros da história. Sendo mais preciso: não todos: alguns ainda acham que gozam de uma liberdade ilusória, contra outros já foi aberto o inquérito, outros ainda já se encontram no banco dos réus. Quanto a mim, considero ter recebido a sentença condenatória. Depois de sentenciado, a gente tem muito tempo, desaparecem inúmeras preocupações e problemas cotidianos, assim a pessoa pode dedicar-se aos estudos sérios, por exemplo, sobre o sistema de carceragem, ou simplesmente filosofar (HERBERT, 2008b, p. 109).

Para terminarmos essa breve exposição sobre a história monstruosa na obra de Herbert, vejamos mais um poema:

\section{Ela ajeitava seus cabelos}

Ela ajeitava seus cabelos antes de dormir diante do espelho Aquilo durava uma eternidade Entre uma e outra flexão do braço no cotovelo

Passavam-se eras Dos cabelos silenciosamente se derramavam os soldados da segunda legião chamada de Augusta Antoniniana os companheiros de Rolando artilheiros de Verdun com dedos fortes firmava a glória acima de sua cabeça Aquilo durou tanto que quando finalmente iniciou sua gingante caminhada até mim meu coração até então tão obediente parou e sobre a pele apareceram os grossos grãos de sal (HERBERT, In: KILANOWSKI, 2018, p. 664)

Podemos entender que na imagem da amante que deixa o amante fascinado, ansioso na espera e apavorado, o eu lírico projeta a imagem da história. A mesma história, fascinante com sua narrativa, com a beleza dos heroísmos humanos e, no fundo, apavorante, acaba penetrando até a vida íntima do poeta. As pessoas estigmatizadas pela 
história são atingidas de modo tão profundo, que mesmo nos momentos de intimidade não conseguem se desvencilhar dela e a projetam no lugar que deveria ser o lugar de amor e não de uma incessante procissão de batalhas, exércitos e mortes. Em outras palavras, a herança e o deserdamento propostos por Barańczak, por mais que sejam opostos, na verdade fazem parte do mesmo processo: a herança em algum nível já é o deserdamento. A procura pela tradição no Herbert, ao mesmo tempo em que procura resgatar os valores da herança, o faz da posição do deserdamento. Não poder viver no mundo legado, nos valores legados, na cidade de infância, sem conseguir "entrar na nova corrente de vida" (HERBERT, Prólogo, In: KILANOWSKI, 2018, p. 647) é viver no deserdo.

Mas a história na vida Herbert acaba tendo vários rostos. Um deles é o dos temíveis “agentes de Leviatã" (HERBERT, Jonas, In: KILANOWSKI, 2018, p. 647), funcionários do serviço secreto polonês, $\mathrm{SB}^{3}$, e os dos outros países do bloco comunista. Análises detalhadas das pastas com atas de operações de SB contra Herbert podem ser encontradas nos artigos do historiador Grzegorz Majchrzak (2006, 2008, 2019) e no trabalho dele em conjunto com Małgorzata Ptasińska Wójcik (2005). O tema é investigado também pelas principais biografias de Herbert escritas por Joanna Siedlecka (2018, p. 522-592, capítulos Dosięgnie mnie ręka tych panów e Przystań) e Andrzej Franaszek (2018, v. 2, p. 286302 , capítulo Securitas). Cabe ressaltar que as atas de SB foram parcialmente destruídas, os codinomes dos informantes mais importante frequentemente eram propositadamente apagados e as informações contidas nesses documentos tem que ser analisadas com muito cuidado. Eram afinal produtos dos agentes que queriam mostrar sua utilidade e apresentavam suas interpretações das falas e posturas do "objeto de procedimento".

Os exemplos de perseguição ultrapassariam o limite deste ensaio. Um dos mais conhecidos acontece em 1969 quando o poeta, depois de ter passado um tempo no Ocidente volta para o país para renovar o passaporte. Cabe lembrar que os passaportes

\footnotetext{
${ }^{3}$ Służba Bezpieczeństwa, SB, o que se traduz como Serviço de Segurança, era o órgão do Ministério dos Assuntos Internos que funcionou na República Popular da Polônia desde 1956 até a queda do sistema em 1989, sendo dissolvido somente em 1990. Antes de 1956, ou seja, o "degelo", o órgão funcionava como: Divisão de Segurança Pública (Resort Bezpieczeństwa Publicznego) (1944) que foi transformado em Ministério de Segurança Pública (Ministerstwo Bezpieczeństwa Publicznego) (1944-1954), Comitê de Assuntos de Segurança Pública (1954-1956), todos eles popularmente conhecidos como Urząd Bezpieczeństwa (Departamento de Segurança, UB) ou Ubecja que depois virou Esbecja. A SB tinha como seus objetivos espionar e controlar os cidadãos para proteger o sistema, sendo uma espécie de serviço de espionagem interna e externa, pois incluía também os serviços de inteligência. Na sua história o órgão contabiliza inúmeros crimes de repressão, assassinatos, chantagens, infiltrações na vida privada das pessoas, assim como seus correspondentes mais conhecidos nos países do bloco comunista: KGB, Stasi ou Securitate.
} 
no Estado comunista totalitário eram posse do Estado e não do cidadão, que precisava requerê-los ao Estado a cada vez que queria viajar e devolvê-los assim que voltasse. Além de transformar assim o país numa gigantesca prisão (por essa e por outras maneiras), era um modo eficiente de corromper os cidadãos, forçando os a prestar informações sobre os emigrantes, estrangeiros, comportamento dos poloneses no exterior, em suma torná-los colaboradores do sistema policial em troca da concessão do passaporte. A chantagem continuava posteriormente, só que dessa vez um dos seus elementos era: diremos a todos que foi o nosso colaborador, ou seja, um traidor das pessoas com as quais se encontrou e com as quais convive. Herbert, que dos quase 45 anos da existência da Polônia comunista passou por volta de 20 anos fora de suas fronteiras, foi um alvo perfeito para as operações desse tipo. Tinha consciência que indo renovar seus documentos num Consulado ou numa Embaixada da Polônia teria que se encontrar com os asseclas do sistema. Não tinha consciência, que mesmo este tipo de encontros poderia ser utilizado contra ele: no final dos anos setenta a intelligentsia da Polônia comunista estava preparando uma operação para comprometer o poeta, considerando a possibilidade de informar os serviços especiais da República Federal da Alemanha que Herbert encontrava-se com os agentes de serviço secreto, disfarçados de diplomatas, sugerindo que era um colaborador secreto do serviço de espionagem (MAJCHRZAK, 2008, p. 49).

No entanto, Herbert não tinha dúvidas que iria encontrar-se com o dragão quando foi obrigado a aceitar o encontro com o serviço secreto para conseguir obter o passaporte. Quando em 1969 Herbert volta emergencialmente para a Polônia para cuidar da mãe doente, dois dias depois de retornar recebe o telefonema de SB. Inicia então o jogo com eles para poder obter o passaporte e sair da Polônia. É um momento no qual a sua esposa lhe aguarda em Berlim e Herbert precisa do passaporte, pois recebeu a melhor oportunidade financeira da sua vida: um contrato de professor nos Estados Unidos. Aceita então o convite para conversar (ou melhor, ser interrogado), mas de imediato quebra também a cláusula de sigilo, exigida nos tais encontros, espalhando a torto e a direito a informação de que está se encontrando com os agentes. Vejamos uma das descrições do encontro enviada para Czesław Miłosz (1911-2004), que morava então em California:

Me telefonaram no segundo dia depois da chegada, quando cuidava da mãe doente. [...] Depois aconteceram regular e diariamente "as conversas" que duravam longas horas. Não na repartição, de jeito nenhum, mas no hotel Metropol, num andar alto com a janela aberta para o pátio. Poderia me acontecer de sair por essa janela para não voltar nunca mais e os amigos diriam que me embebedei e que sempre tive tendências niilistas e ploft. [...] Adoeci com isso (depressão, insônia), mas agora já está tudo bem (HERBERT, MIŁOSZ, 2006, p. 104-105). 
Herbert após conseguir o passaporte não aparece no último interrogatório marcado e pede para o compositor Krzysztof Penderecki (1933-2020), que tinha um passaporte ilimitado e naquela época passava parte de seu tempo em Berlim, para levá-lo de carro para o Berlim Ocidental, somente em Berlim revelando ao amigo que estava praticamente contrabandeando um fugitivo (de acordo com: HERBERTOWA, 2014, p. 143). Vale a pena lembrar que no dia em que Herbert escreveu a citada carta para Miłosz, um antigo amigo dele, Jerzy Zawieyski (1902-1969), escritor e membro do Conselho do Estado que teve coragem de publicamente criticar o governo durante a perseguição aos judeus, estudantes e membros de intelligentsia em março de 1968, caiu da janela nas circunstâncias obscuras. Zawieyski recuperava-se de um derrame sofrido em consequência dos ataques das autoridades e estava parcialmente paralisado. A versão oficial sobre o suicídio pode ser contradita pela versão dos próximos do autor e dos médicos que, além de não observar nenhum sinal que poderia justificar tal ação, diziam ser pouco provável que o semiparalisado Zawieyski conseguisse subir sozinho na janela, com parapeito muito alto e situada distante da sua cama.

Não foi à toa que a polícia secreta foi comparada num dos poemas a planta-jarro, que atrai suas vítimas com promessas para depois aprisioná-las e matá-las:

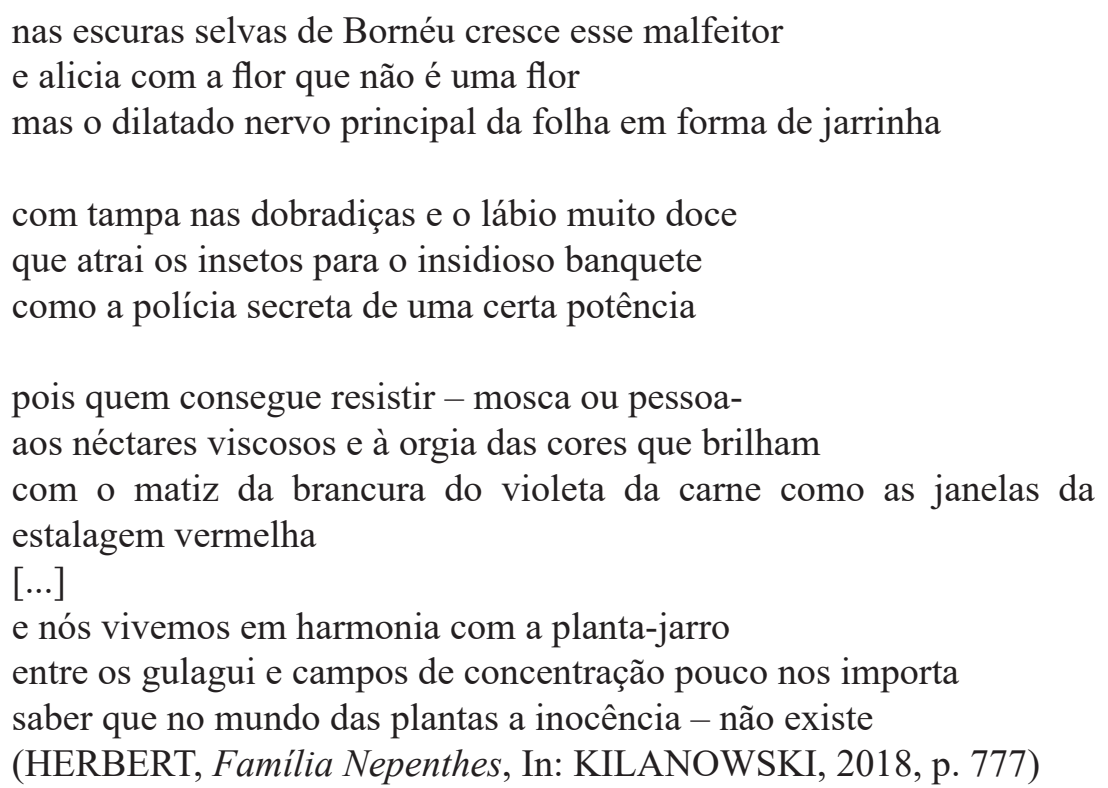

A convivência pacífica com a planta-jarro de novo ressalta a ideia de que a nossa visão da história e da natureza são romantizadas. E que a polícia secreta assim como gulagui e campos de concentração fazem parte do mundo sem inocência, da história, assim como 
as planta-jarro faz parte do mundo sem inocência, da natureza. Vale ressaltar que a "polícia secreta de uma certa potência" nesse poema pode ser alusão à NKVD que, em 1945, convidou para as negociações as autoridades do Estado Polonês, que da clandestinidade organizaram a luta contra os nazistas durante a guerra. Em seguida os 16 líderes foram sequestrados, levados clandestinamente a Moscou onde foram condenados numa farsa jurídica, alguns deles morrendo (ou sendo assassinados) nas prisões soviéticas.

Os encontros de Herbert com SB de alguma forma ecoam no poema "O interrogatório do anjo" que mostra as torturas às quais o anjo é submetido até ser destruído moralmente. O poema pode ser lido também como um relato de torturas a que foram submetidos aqueles da sua geração que ativamente se opunham aos nazistas como membros de Exército da Pátria (Armia Krajowa) e depois eram presos, torturados e assassinados pelo serviço secreto do estado comunista.

\title{
O interrogatório do anjo
}

\author{
Quando está diante deles \\ na sombra da suspeita \\ ainda está todo \\ feito da matéria da luz \\ os éones dos seus cabelos \\ são presos numa madeixa \\ de inocência \\ depois da primeira pergunta \\ o sangue aflui às bochechas \\ o sangue é distribuído \\ pelos instrumentos e pelo interrogatório \\ com ferro uma vara \\ e fogo lento \\ determina-se os limites \\ do seu corpo \\ um golpe nas costas \\ fixa a coluna \\ entre a poça e a nuvem \\ após algumas noites \\ a obra está concluída \\ a garganta de couro do anjo \\ está cheia de consentimento pegajoso
}




\author{
como é belo o instante \\ quando cai de joelhos \\ incorporado na culpa \\ saturado de conteúdo \\ a língua balança \\ entre os dentes quebrados \\ e a confissão \\ penduram-no de cabeça para baixo \\ dos cabelos do anjo \\ escorrem gotas de cera \\ formam sobre o piso \\ uma simples profecia \\ (HERBERT, In: KILANOWSKI, 2018, p. 655)
}

A pesquisa feita por Majchrzak (2006, 2008, 2019) nos arquivos de SB revela as informações que os agentes tinham sobre o poeta: suas tendências ao alcoolismo, fragilidade psíquica, caráter honrado, mas também nomes de seus médicos, datas de internações e remédios utilizados, informes sobre a vida financeira (SB atuou algumas vezes impedindo contratos que poderiam lhe ser oferecidos). Todas essas informações eram utilizadas contra ele. Tanto durante as provocações organizadas que resultavam em atitudes agressivas do poeta nos momentos de instabilidade psicoemocional, quanto em falsos boatos espalhados entre seus colegas que poderiam provocar o isolamento do poeta, quanto, por fim, numa longa campanha do serviço secreto polonês exercendo influências para que os escritores que se pronunciavam, mais ou menos abertamente contra o regime e que orbitassem o prêmio Nobel tivessem as chances diminuídas de consegui-lo. A lista de lobby contra continha os nomes como Stanisław Lem, Witold Gombrowicz e Zbigniew Herbert. As campanhas de difamação (por exemplo, inventando pretenso antissemitismo de um artista) ou de aproveitar problemas reais (como a doença psíquica de Herbert), assim como as de lobby a favor dos candidatos do sistema eram conduzidas pelos funcionários de SB no país e no mundo junto às pessoas influentes e do comitê do Nobel que visitavam a Polônia a convite de autoridades comunistas (SIEDLECKA, 2018, p. 531-535).

O interesse do serviço secreto por Herbert inicia em 1960, de acordo com os documentos preservados. Como foi dito, tudo indica que uma grande parte deles foi destruída ou limpa, uma vez que no seu dossiê não constam nomes ou codinomes de agentes, mas às vezes é possível encontrar suas denúncias contra Herbert em seus dossiês pessoais. Até agora foram encontrados apenas 4 volumes de atas de arquivos referentes 
a Herbert. Para comparar alguns dos seus amigos literatos tem entre 10 e 15 volumes preservados (SIEDLECKA, 2018, p. 522). Isso provoca reflexão a respeito da quantidade de informações que foram destruídas e apagadas e indagação sobre o que estavam tratando os arquivos destruídos.

O interesse inicial é repentinamente encerrado em 1971 e volta a ser reaberto logo em seguida com outro codinome (primeiro "Bem", segundo "Herb") e só é encerrado cerca de meio ano depois das eleições que abriram o caminho para a Polônia livre em 1989. Nos anos setenta, o poeta já contava com vigilância contínua. Ele mesmo engajou-se depois da volta para o país em 1971 no movimento da oposição democrática, trabalhando ativamente na União dos Literatos. Com esse tempo, entre muitas outras provocações, estão relacionadas duas: a compra de casa própria e uma suposta tentativa de envenenamento. Enquanto o primeiro caso foi investigado detalhadamente por Siedlecka, o segundo carece de comprovações, além das palavras do próprio poeta que relatou ter sido envenenado ${ }^{4}$. Durante XIX Assembleia Geral da União dos Literatos em Poznań em 1975, Herbert estava ativamente engajado na oposição contra os mandantes do sistema na organização. Herbert passou muito mal, quase desmaiando ao tomar água no quarto do Hotel onde acontecia a assembleia. $\mathrm{O}$ atendimento de pronto socorro médico não diagnosticou intoxicação alimentar, sugerindo reação alérgica. $\mathrm{O}$ poeta convencido da tentativa de envenenamento tentou primeiro levar a garrafa para exame na vigilância sanitária e depois de receber recusa foi registrar a ocorrência, mas a garrafa que levou e que poderia servir como prova foi extraviada nos procedimentos policiais. Sabemos que a SB ocupava vários quartos naquele hotel, abertamente intimidando os literatos e que Witold Dąbrowski que tomou um gole da mesma água também passou mal. Depois da Assembleia, Herbert diminuiu sua atividade na União e um agente da SB escreveu na sua pasta: "Como efeito de numerosas ações político-operacionais, o grupo de literatos conhecidos por suas posturas antissocialistas e ligações com centros anticomunistas no Ocidente foi eliminado da direção da União" (MAJCHRZAK, 2008, p. 52). E como as ordens de executar esse tipo de ações eram dadas oralmente e ações não eram registradas em atas, ou registradas usando a linguagem velada e oficial, como a citada acima, provavelmente nunca saberemos o que efetivamente aconteceu.

A questão da ingerência de SB na compra de casa é documentada pela investigação

\footnotetext{
${ }^{4}$ Enquanto Andrzej Franaszek que dedica ao caso uma parte do capítulo Tajemnica Hotelu Polonez (2018, v. 2, p. 427-457) duvida da versão do envenenamento, Joanna Siedlecka que investiga detalhadamente o caso (2018, capítulo Czlen prezydiuma, p. 388-401) reúne as opiniões de vários participantes dos acontecimentos parece sugerir a possibilidade dele efetivamente ter acontecido.
} 
aterradora e reveladora de Joanna Siedlecka (2018, p. 559-592). Quando os Herbert voltam dos Estados Unidos, trazem consigo dinheiro com o qual seria possível finalmente comprar a moradia própria. Conseguem achar o apartamento que lhes agrada e trocam a quitinete de Herbert ${ }^{5}$ por ele, pagando a diferença com parte das economias. Somente depois da compra efetuada recebem a informação das autoridades que o lugar foi ocupado para o uso do Ministério dos Assuntos Internos (leia-se: SB) - ficaram sem dinheiro e sem morada. Era assim que as autoridades queriam convencer o incômodo poeta a deixar a Polônia de vez. Depois de três anos de tentativas, morando no apartamento de amigos poetas Julia Hartwig e Artur Międzyrzecki, que estavam trabalhando naquela época em Estados Unidos, os Herbert conseguem finalmente resolver o problema. Quando a esposa de Herbert resolve tentar intervir na seção da cultura do PZPR ${ }^{6}$, finalmente são lhes apresentados alguns apartamentos a escolher. Os Herbert escolhem um deles, situado na rua Promenada, grande e situado em localização central, mas numa vizinhança na época bastante complicada. A concessão do apartamento de 140 metros numa casa que depois da guerra foi desapropriada e transformada em moradia comunitária, lembra um pouco a situação de moradia que Herbert descreveu na sua peça Drugi pokój ( $O$ outro quarto). A casa foi tomada dos seus antigos donos e em cada um de seus grandes cômodos foram alojadas várias famílias. No apartamento dos Herbert viviam ainda três famílias e o poeta e sua esposa tiveram que encontrar logradouros para eles, comprá-los e ajudar na mudança e instalação. Para isso tiveram que vender a quitinete de Herbert e o apartamento da mãe dele que viria a morar com eles. O sonho da casa própria, além de drenar todas as economias do casal e obrigá-los a viver na insegurança durante três anos em que viveram na casa dos amigos, resultou ser mais uma armadilha preparada para o poeta. $\mathrm{O}$ apartamento perfeito que lhes foi disponibilizado primeiro ocasionou boatos profissionais dirigidos contra o poeta (se recebeu um apartamento desses, depois da intervenção na PZPR, deve ter concordado em colaborar de alguma maneira, diziam colegas revoltados, na sua maioria literatos do partido, muito bem instalados). Os boatos eram reforçados, pois assuntos, frequentemente sigilosos, que eram tratados nas reuniões da oposição na casa dos Herbert, misteriosamente "vazavam".

Só hoje, depois de anos, graças aos arquivos que não foram até o final "limpos",

\footnotetext{
${ }^{5}$ A quitinete foi conseguida por intermédio de Jerzy Zawieyski em 1958. Antes disso Herbert morava como sublocatário, compartilhando quarto com amigos. Conto um pouco mais detalhes a esse respeito em KILANOWSKI, 2018, p. 116-119.
}

${ }^{6}$ PZPR é a sigla de Polska Zjednoczona Partia Robotnicza (Partido Unificado dos Trabalhadores Poloneses) - o partido comunista que autoritariamente governou o país de 1945 a 1989. 
sabe-se que toda essa luta pelo apartamento era cuidadosamente monitorada e dirigida por SB e que desde início, antes dos Herbert mudarem, durante as reformas foram instaladas na sua casa as escutas de todo quanto é tipo. Para uma escuta fixa poder funcionar naqueles tempos, era preciso que numa das paredes de casa houvesse um espaço do qual o equipamento de gravações pudesse ser operado. Consequentemente um dos vizinhos teria que ser agente. E tais condições foram cumpridas. Quando se lê inicialmente os informes da fonte operacional "Herb" a quantidade e detalhamento de informações indicam alguém muito próximo. Sabemos de detalhes de visitas, de internações do poeta, dos seus assuntos familiares.

Até uma inesperada descoberta que aconteceu há 15 anos, ao se ler as informações as suspeitas poderiam ser dirigidas contra esposa do poeta, como uma das poucas pessoas que teriam acesso a todas as informações. E as suspeitas eram cuidadosamente disseminadas por agentes infiltrados entre os conhecidos do casal, primeiro contra o poeta, depois contra a sua esposa. As ações de SB não tinham limites: na história da literatura polonesa pós-guerra ficou famoso o caso, confirmado somente em 2002, da agente que se casou com o escritor oposicionista, Paweł Jasienica (1909-1970), para poder cumprir melhor a sua missão. Felizmente a grande maioria dos envolvidos conheciam os métodos operacionais de SB e os boatos disseminados nunca foram levados a sério. Em 2005, por inspiração de Katarzyna Herbert foi publicada uma parte dos materiais reunidos nos arquivos de SB de 1967-1970 (MAJCHRZAK, PTASIŃSKA-WÓJCIK, 2005).

A limpeza feita nos arquivos das operações contra Herbert recorda aquilo que viveu Herta Müller, ao tentar descobrir a história de sua perseguição na sua pasta de Securitate e que descreveu no artigo para o Die Zeit, intitulado: Die Securitate ist noch im Dienst (A securitate continua no serviço) (MÜLLER, 2009). Partes cuidadosamente ou menos cuidadosamente apagadas, fazem com que nos movimentemos entre essas informações como o Senhor Cogito diante de seu amorfo monstro do poema. Na Polônia em 2005, sete anos depois da morte do poeta e 16 anos depois da queda do sistema, descobriu-se que o vizinho que morava em cima dos Herbert, diretor do cinema ao mesmo tempo conhecido e pouco produtivo foi um dos agentes secretos de SB. Ao longo da sua longa carreira profissional (1965-2005) produziu apenas 3 longas-metragens. Dois deles tidos como chacota e crítica do comunismo nos tempos do regime e um depois da queda dele, que causou a queda política de um dos antigos opositores dos comunistas. As lacunas nos registros da pasta de codinome "Herb", que continha relatórios das escutas coincidem com suas estadas no estrangeiro nos anos setenta e oitenta. O caso da observação e escuta de Herbert foi encerrado cerca de seis meses depois da queda do sistema. Embora 
a suspeita contra o diretor pese forte, nada pode ser provado e continuamos diante da informe neblina como o Senhor Cogito.

Façamos só um curto exercício de empatia. Como a pessoa que luta pela estabilidade psicoemocional todo dia, tomando medicamentos pesados, iria se sentir ao descobrir que todo mundo sabe das suas internações em hospícios, mantidos cuidadosamente em segredo, que as pessoas desconhecidas lhe revelam, como se fosse por acaso, as informações íntimas? Como a pessoa assim consegue definir se está louca ou se está na teia de aranha dos hábeis agentes? E como sabendo dos momentos frágeis é fácil induzir tal pessoa para os atos pelos quais ela mesma depois vai sentir arrependimento?

Devemos lembrar que o anjo interrogado no poema citado, na verdade configura uma de poucas exceções. Normalmente os anjos de Herbert são mais terríveis. Talvez os Sete anjos do poema reflitam em algum nível a presença dos agentes invisíveis do monstro policial? Se pensarmos que num outro poema, Nos portões do vale, estavam fazendo até o papel dos guardas de um campo de extermínio ${ }^{7}$, a possibilidade de leitura parece provável:

\section{Sete anjos}

Toda manhã vêm sete anjos. Entram sem bater. Um deles, com um movimento brusco, tira do meu peito o coração. Encosta nos seus lábios. Os outros fazem o mesmo. Então suas asas murcham e suas faces prateadas tornam-se purpúreas. Vão embora pesadamente batendo os tamancos no chão. Deixam o coração na cadeira como uma panelinha vazia. É preciso enchê-lo durante o dia todo, para que de manhã os anjos não saiam prateados e alados. (HERBERT In: KILANOWSKI, 2018, p. 594)

A presença dos agentes na obra de Herbert é discreta, talvez até mais discreta que as ações deles ao seu redor. Sabemos que tinha como costume vociferar alto contra os agentes postados num carro na porta dele, que os enfrentava sempre que fosse possível, mas de fato lutava contra um monstro indefinido. Ao mesmo tempo a obsessão com eles fica aparente até num de seus poemas mais luminosos $A$ oração do Senhor Cogito - o viajante, quando diz: “- permite ó Senhor que eu não pense sobre os meus cinzentos tolos perseguidores de olhos aquosos quando o sol se puser no Mar Jônico verdadeiramente indescritível” (HERBERT In: KILANOWSKI, 2018, p. 722).

Surpreende a semelhança das visões dos dois literatos que tiveram que lidar com

\footnotetext{
${ }^{7}$ Mais a esse respeito pode ser lido em PAIVA, 2011 e em KILANOWSKI, 2018, p. 293, 327 e 424.
} 
os serviços secretos de seus próprios países. Herta Müller, ao narrar as tentativas de encontrar a verdade na sua pasta de Securitate escreve: "eles cuidaram para que, na era pós Ceausescu, Securitate se tornasse um monstro abstrato" (MÜLLER, 2009) Herbert por sua vez na prosa poética intitulada "Securitas" escreve: "Securitas pertence ao gênero de monstros. O que são diante dela aqueles monstros-gigantes infantis, dragões, semihumanos, semianimais, os híbridos mal costurados. Securitas é mais semelhante a nós -é um monstro com rosto humano" (HERBERT, 2008a, p. 81).

O poema intitulado $O$ monstro do Senhor Cogito pode ser lido de várias maneiras. Alguns tentaram ver no monstro o sistema totalitário comunista, outros a doença depressiva que assolou a vida do poeta, outros ainda um niilismo axiológico oriundo do deserdamento (FRANASZEK, 1998, p. 178-179; BARAŃCZAK, 1986, p. 38). Uma leitura que queira ver nele, por exemplo, o consumismo também se justificaria perfeitamente. No entanto, à luz das informações sobre a influência de SB na vida Herbert apresentadas acima, de uma forma inevitavelmente reduzida, mais uma possibilidade de entendimento de monstro se impõe:

\section{O monstro do Senhor Cogito}

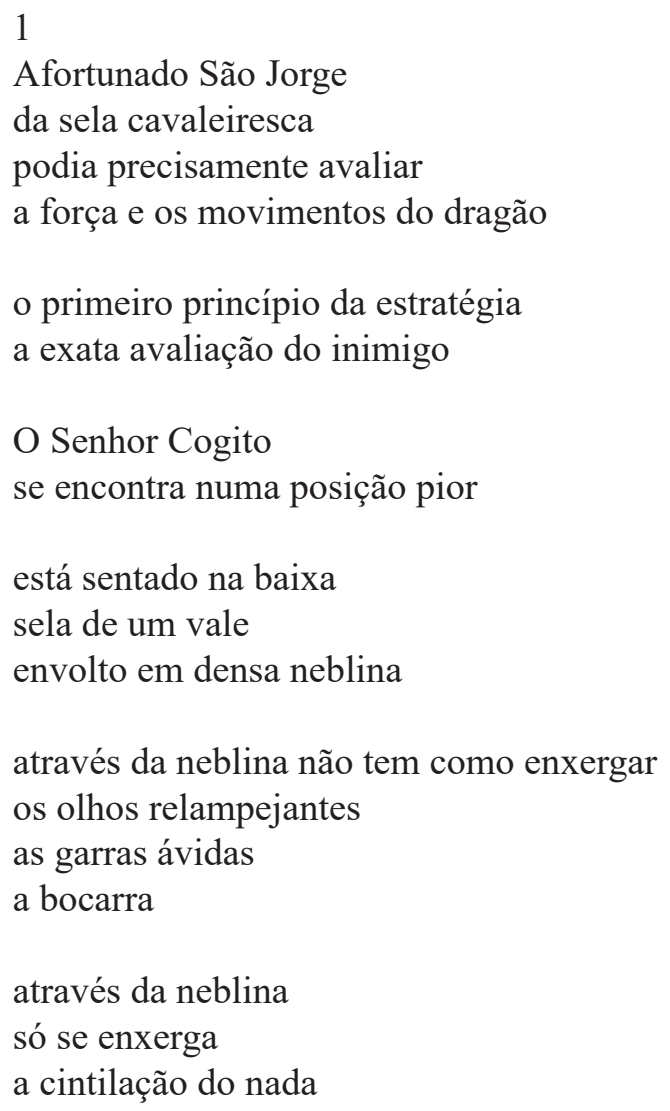


o monstro do Senhor Cogito

carece de dimensões

é difícil descrevê-lo

escapa às definições

é como uma imensa depressão

que se estende sobre o país

não se deixa transpassar

com uma pena

com um argumento

com uma lança

se não fosse pelo peso sufocante

e a morte que desfere

poderíamos pensar

que é uma alucinação

uma doença da imaginação

mas ele existe

existe com certeza

como monóxido de carbono ele enche totalmente

as casas os templos os bazares

envenena os poços

destrói as construções do pensamento

cobre o pão com mofo

a prova da existência do monstro

são suas vítimas

é uma prova indireta

porém suficiente

2

dizem as pessoas sensatas

que é possível conviver

com o monstro

só é preciso evitar

os movimentos bruscos

a fala brusca

em caso de perigo 
assumir a forma

de uma pedra ou de uma folha

escutar a sábia Natureza

que aconselha o mimetismo

respirar superficialmente

fingir que não existimos

o Senhor Cogito no entanto

não gosta da vida de faz de conta

queria lutar

com o monstro

na arena

sai então ao amanhecer

para o subúrbio sonolento

munido por precaução

de um longo objeto pontiagudo

chama o monstro

pelas ruas vazias

insulta o monstro

provoca o monstro

audaz escaramuçador

de um exército inexistente

grita -

apareça vil covarde

através da neblina

só se vê

a enorme fuça do nada

o Senhor Cogito quer travar

um combate desigual

deveria acontecer

o mais rápido possível

antes que sobrevenha

o abatimento por inércia

a morte comum sem glória

a asfixia por informidade

(HERBERT, In: KILANOWSKI, 2018, p. 741) 
O monstro do Senhor Cogito é indefinido e, como vimos, serve de máscara para várias realidades desde os totalitarismos, os capitalismos, serviços secretos, até a condição humana, as nossas indefinições, confusões, desânimos, cansaços e preguiças. Creio que podemos dizer que seu corpo indefinido seja feito de medo. O medo que é instrumento de serviços secretos e da maioria dos governos. O medo sempre presente ao redor de nós, o medo que nos priva da nossa herança, que nos faz procurar os falsos messias, que nos faz esquecer. Os espaços nos quais os valores são turvados ou apagados, os espaços marcados pela crescente amorfia, o deserdamento são a nossa realidade. Se por um lado a herança herbertiana pode ser específica, polonesa ou centro-europeia, se o seu oposto complementar pode estar ligado com a desorientação trazida pela guerra e totalitarismos, por outro, podemos observar perfeitamente o avanço do território do deserdamento na nossa contemporaneidade. Acometida de Mal de Alzheimer progressivo no que se refere à tradição e à história, obrigada a perceber a complexidade de tudo e, portanto, a relativizar quase todos os valores, a nossa época encontra cada vez mais dificuldades de estabelecer parâmetros claros relativos ao foco sob o qual vê o mundo. A nostalgia dos valores simplificados curiosamente cria a saudade do discurso que foge da amorfia e resgata as mitologias claras e patriarcais. A ausência de um substrato mítico forte no discurso político e midiático aliado à fuga da realidade oferecida pela realidade virtual abre espaço para que o sonho da razão crie monstros. Os monstros amorfos, como o do Senhor Cogito, paralisam e permitem o surgimento dos monstros que apelam à volta da herança, geralmente simplificada ao discurso patriarcal e à recuperação da grandeza, supostamente perdida, e da pureza, frequentemente étnica ou fundamentalista. E assim esse poema, como a maioria dos poemas de Zbigniew Herbert que reúnem várias camadas sobrepostas com uma universalidade surpreendente, ganha uma inesperada atualidade apesar de ter sido publicado há quase quarenta anos do outro lado do mundo. 


\section{REFERÊNCIAS:}

ADAMOWSKA, Joanna. Różewicz i Herbert. Aksjologiczne aspekty twórczości. Cracóvia: Universitas, 2012.

BARAŃCZAK, Stanisław. Uciekinier z utopii. O poezji Zbigniew Herberta. Londres: Polonia Book Fund, 1984 (versão em inglês: BARAŃCZAK, Stanisław. A Fugitive from Utopia. The Poetry of Zbigniew Herbert. Cambridge: Harvard University Press, 1987).

CATALUCCIO, Francesco. Il Signor Cogito. In: FRANASZEK, Andrzej (Org.), Poznawanie Herberta 2, Cracóvia: Wydawnictwo Literackie, 1999. p. 35-37.

FRANASZEK, Andrzej (Org.). Poznawanie Herberta 2. Cracóvia: Wydawnictwo Literackie, 1999.

FRANASZEK, Andrzej. Ciemne źródło. O twórczości Zbigniew Herberta. Londres: Puls, 1998.

FRANASZEK, Andrzej. Herbert. Biografia. V.1-2. Cracóvia: Znak, 2018.

HERBERT, Zbigniew; MlŁOSZ, Czesław. Zbigniew Herbert/Czesław Miłosz. Korespondencja. Varsóvia: Fundacja Zeszytów Literackich, 2006.

HERBERT, Zbigniew. Król mrówek. Cracóvia: a5, 2008a.

HERBERT, Zbigniew. Mistrz z Delft. Varsóvia: Fundacja Zeszytów Literackich, 2008b.

HERBERT, Zbigniew. Wiersze zebrane. Cracóvia: a5, 2008c.

HERBERTOWA, Katarzyna. Ze Zbigniewem Herbertem mój życiorys. In: ROMANIUK, Anna (Org.). Wierność. Wspomnienia o Zbigniewie Herbercie. Varsóvia: PWN, 2014, p. 134-168.

KILANOWSKI, Piotr. “Queria permanecer fiel à clareza incerta...": Sobre poesia de Zbigniew Herbert. 876 p. Tese (Doutorado em Literatura) - Centro de Comunicação e Expressão, Programa de Pós-Graduação em Literatura, Universidade Federal de Santa Catarina, Florianópolis, 2018.

LIGĘZA, Wojciech (Org.) Portret z początku wieku: twórczość Zbigniewa Herberta kontynuacje i rewizje. Lublin: Gaudium, 2005. 
MAJCHRZAK, Grzegorz, PTASIŃSKA-WÓJCIK, Małgorzata. Kryptonim „Bem”. Sprawa operacyjnego rozpracowania Zbigniewa Herberta 1967-1970. Zeszyty Historyczne, Paris, n. 153, p. 5-60, 2005.

MAJCHRZAK, Grzegorz. Operacja „Bem”. Gazeta Polska, Varsóvia, n. 43, p. 14-15, 2006.

MAJCHRZAK, Grzegorz. Rozmowy z "Panem Cogito". Zbigniew Herbert na celowniku peerelowskiego wywiadu. Pamięć $i$ sprawiedliwość, Varsóvia, n. 33, p. 478-493, 1/2019.

MAJCHRZAK, Grzegorz. Sprawa Kryptonim „Herb”. Działania Służby Bezpieczeństwa wobec Zbigniewa Herberta w latach siedemdziesiątych i osiemdziesiątych. Biuletyn IPN, Varsóvia, n. 91-92, p. 42-52, 8/9 2008.

MIKOŁAJCZAK Małgorzata. Oblicza historii w poezji Zbigniewa Herberta. In: LIGĘZA, Wojciech (Org.) Portret z początku wieku: tworczość Zbigniewa Herberta - kontynuacje i rewizje. Lublin: Gaudium, 2005. p. 85-109.

MÜLLER, Herta. Die Securitate ist noch im Dienst. Die Zeit, Hamburg, n. 31, 23 jul. 2009. Disponível em: <https://www.zeit.de/2009/31/Securitate>. Acesso em 28 jun. 2020. A versão inglesa publicada em The Guardian está disponível em: $<$ https://www.theguardian.com/books/2009/oct/10/herta-muller-nobel-laureatememoir>. Acesso em 28 jun. 2020.

ROMANIUK, Anna (org.) Wierność. Wspomnienia o Zbigniewie Herbercie. Varsóvia: PWN, 2014.

SIEDLECKA, Joanna. Pan od poezji. O Zbigniewie Herbercie. Segunda edição, ampliada. Varsóvia: Fronda, 2018.

SOUZA, Marcelo Paiva de. Ao vivo, direto do vale de Josafá - algumas reflexões sobre a poesia e a tradução da poesia de Zbigniew Herbert. Tradução em Revista (Online), v. 1, p. 1-12, 2011. Disponível em: <https://www.maxwell.vrac.puc-rio.br/17860/17860.PDF>. Acesso em 28 jun. 2020. 